\title{
Optimal Sanctions When Individuals Are Imperfectly Informed about the Probability of Apprehension
}

\section{Citation}

Lucian Arye Bebchuk and Louis Kaplow, Optimal Sanctions When Individuals Are Imperfectly Informed about the Probability of Apprehension, 21 J. Legal Stud. 365 (1992).

\section{Published Version}

http://www.jstor.org/stable/724486

\section{Permanent link}

http://nrs.harvard.edu/urn-3:HUL.InstRepos:10611800

\section{Terms of Use}

This article was downloaded from Harvard University's DASH repository, and is made available under the terms and conditions applicable to Other Posted Material, as set forth at http:// nrs.harvard.edu/urn-3:HUL.InstRepos:dash.current.terms-of-use\#LAA

\section{Share Your Story}

The Harvard community has made this article openly available.

Please share how this access benefits you. Submit a story.

Accessibility 


\section{CHICAgO JOURNALS}

Optimal Sanctions When Individuals Are Imperfectly Informed about the Probability of Apprehension Author(s): Lucian Arye Bebchuk and Louis Kaplow

Source: The Journal of Legal Studies, Vol. 21, No. 2 (Jun., 1992), pp. 365-370

Published by: The University of Chicago Press

Stable URL: http://www.jstor.org/stable/724486

Accessed: 16/02/2010 20:34

Your use of the JSTOR archive indicates your acceptance of JSTOR's Terms and Conditions of Use, available at http://www.jstor.org/page/info/about/policies/terms.jsp. JSTOR's Terms and Conditions of Use provides, in part, that unless you have obtained prior permission, you may not download an entire issue of a journal or multiple copies of articles, and you may use content in the JSTOR archive only for your personal, non-commercial use.

Please contact the publisher regarding any further use of this work. Publisher contact information may be obtained at http://www.jstor.org/action/showPublisher?publisherCode=ucpress.

Each copy of any part of a JSTOR transmission must contain the same copyright notice that appears on the screen or printed page of such transmission.

JSTOR is a not-for-profit service that helps scholars, researchers, and students discover, use, and build upon a wide range of content in a trusted digital archive. We use information technology and tools to increase productivity and facilitate new forms of scholarship. For more information about JSTOR, please contact support@jstor.org. 


\title{
OPTIMAL SANCTIONS WHEN INDIVIDUALS ARE IMPERFECTLY INFORMED ABOUT THE PROBABILITY OF APPREHENSION
}

\author{
LUCIAN ARYE BEBCHUK and LOUIS KAPLOW*
}

\section{INTRODUCTION}

G

ARY BECKER's classic article introduced the idea that enforcement effort and sanctions are substitutes in enforcement. ${ }^{1}$ A lower level of enforcement effort can be offset by increasing sanctions, which economizes on enforcement costs. Even activities involving little harm should receive the maximal sanction; the probability of apprehension for such acts may be reduced in order to avoid overdeterrence. Subsequent articles have explored and qualified Becker's insight concerning optimal enforcement policy. ${ }^{2}$

* Both of Harvard University and the National Bureau of Economic Research. We thank Howard Chang, Jesse Fried, Mitch Polinsky, and Steve Shavell for helpful comments and the John M. Olin Foundation for financial support. Lucian Bebchuk's work has also been supported by the National Science Foundation.

$\rightarrow$ Gary S. Becker, Crime and Punishment: An Economic Approach, 76 J. Pol. Econ. 169 (1968).

2 The literature has offered various explanations for why nonmaximal sanctions may be desirable: for risk aversion, see Louis Kaplow, The Optimal Probability and Magnitude of Fines for Acts That Definitely Are Undesirable, 12 Int'l Rev. L. \& Econ. 3 (19S $\rightarrow$ A. Mitchell Polinsky \& Steven Shavell, The Optimal Tradeoff between the Probability and Magnitude of Fines, 69 Am. Econ. Rev. 880 (1979); for nonmonetary sanctions, see Louis Kaplow, A Note on the Optimal Use of Nonmonetary Sanctions, 42 J. Pub. Econ. 245 $(195 \rightarrow$ A. Mitchell Polinsky \& Steven Shavell, The Optimal Use of Fines and Imprisonment, 24 J. Pub. Econ. 89 (1984); for avoidance costs, $\rightarrow$ Arun S. Malik, Avoidance, Screening and Optimum Enforcement, 21 Rand J. Econ. 341 (1990); for marginal deterrence, see Steven Shavell, A Note on Marginal Deterrence, Int'l Rev. L. \& Econ. (forthcoming); for general enforcement, see Dilip Mookherjee \& Ivan P. L. Png, Monitoring versus Investigation in Law Enforcement and Regulation (unpublished manuscript, Univ. California, Grad. School Mgmt. 19 $\rightarrow$ Steven Shavell, Specific versus General Enforcement of Law, 99 J. Pol. Econ. 1088 (1991); for individuals' differences in wealth, resulting in differences in the maximum feasible fine, $\rightarrow$ A. Mitchell Polinsky \& Steven Shavell, A Note on

[Journal of Legal Studies, vol. XXI (June 1992)]

(C) 1992 by The University of Chicago. All rights reserved. 0047-2530/92/2102-0006\$01.50 
An implicit assumption in Becker's analysis of optimal sanctions, which has been carried over to subsequent investigations of optimal enforcement policy, is that individuals accurately observe the enforcement probability set by the government. ${ }^{3}$ While there presumably is a positive relationship between actual and perceived levels of enforcement, it is implausible that individuals' probability estimates are generally accurate, particularly when the probability is extremely low. Will most individuals know that the probability of being ticketed for double parking is 2.74 percent while that for speeding is 0.89 percent? Indeed, survey evidence on individuals' perceptions indicates that estimates vary widely. ${ }^{4}$

This article reconsiders the problem of optimal sanctions when actors' information about the probability of apprehension is imperfect. We do not assume that actors err systematically in one direction or the other. Rather, we assume that individuals observe the probability of apprehension with some noise; consequently, some individuals' estimates are too high, and others' too low, with the average being unbiased.

Our primary result is that, when individuals are imperfectly informed in this manner, it may not be optimal to set the sanction at the highest feasible level. The reason is that a given error in observing the probability of apprehension affects the expected sanction in an amount that depends on the level of the sanction. To illustrate this, suppose that an act causes

Optimal Fines When Wealth Varies among Individuals, 81 Am. Econ. Rev. 618 (1991); for individuals' imperfect information about whether acts are subject to sanctions, $\rightarrow$ Louis Kaplow, Optimal Deterrence, Uninformed Individuals, and Acquiring Information about Whether Acts Are Subject to Sanctions, 6 J. L. Econ. \& Org. 93 (1990); and for differences in the actual probability of apprehension, see Lucian A. Bebchuk \& Louis Kaplow, Optimal Sanctions When Individuals Are Imperfectly Informed about the Probability of Apprehension (Discussion Paper No. 88, Harvard Law School, Program in Law and Economics 1991).

${ }^{3}$ Sah independently draws attention to the possibility (and discusses in greater depth the plausibility of the assumption) that individuals' estimates of the probability of apprehension may differ. $\rightarrow$ Raaj K. Sah, Social Osmosis and Patterns of Crime, 99 J. Pol. Econ. 1272 (1991). His article, however, focuses on positive analysis: he develops a model of how different estimates may come about and evolve over time and draws implications for how crime rates may be affected. In contrast, we explore the normative question-which he explicitly reserves-of how different probability estimates affect optimal enforcement policy.

${ }^{4}$ Sah discusses some of the findings. See $i d$. Work reporting or employing such evidence includes James J. Teevan, Jr., Perceptions of Punishment: Current Research, in Perception in Criminology (Richard L. Henshel \& Robert A. Silverman eds. 1975); Claude Montmarquette \& Marc Nerlove, Deterrence and Delinquency: An Analysis of Individual Data, $1 \mathrm{~J}$. Quantitative Criminology 37 (1985); Jerry Parker \& Harold G. Grasmick, Linking Actual and Perceived Certainty of Punishment, 17 Criminology 366 (1979); Pamela Richards \& Charles R. Tittle, Socioeconomic Status and Perceptions of Personal Arrest Probabilities, 20 Criminology 329 (1982). 
a harm of 10 . The maximum possible sanction is 500 , so optimal deterrence could be achieved with a probability of 2 percent. Alternatively, one could employ a sanction of 100 and a probability of 10 percent. Suppose, however, that half the individuals overestimate the probability by one percentage point and the other half underestimate it by the same amount. For the first regime, half face an expected sanction of 15 (3 percent $\times 500)$, and half face an expected sanction of 5 (1 percent $\times$ 500); for the alternative regime, half face $11(11$ percent $\times 100)$ and half $9(9$ percent $\times 100)$. Clearly, under the former regime, there will be greater overdeterrence for the individuals who overestimate the probability and greater underdeterrence for those who underestimate it than under the latter regime. If the resulting loss in welfare exceeds the cost of raising the actual probability from 2 percent to 10 percent, the latter regime would be superior.

This example assumes that the magnitude of noise in individuals' estimates is independent of the probability of apprehension. The phenomenon, however, is more general. Even if the magnitude of errors in individuals' estimates increases as the probability of apprehension increases, there will still be an improvement in behavior as long as the relative size of the error falls. Thus, in the example, as long as individuals' errors are less than 5 percentage points when the probability of apprehension is raised to 10 percent, expected sanctions will be closer together under the regime with a higher probability and lower sanction, and problems of over- and underdeterrence will be less.

In the next section, we present our model and analysis, after which we offer brief concluding remarks concerning the empirical importance of the phenomenon we address.

\section{Model}

\section{A. Framework for Analysis}

Risk-neutral individuals choose whether to commit an act that benefits the actor by $b$, which is assumed to be distributed uniformly in the interval $[0,1]$. Acts impose a social cost, $h$. We assume $h<1$, so that some acts are socially beneficial.

The government chooses a probability of enforcement, $p$, and a sanction, $s$, so as to maximize the sum of individuals' benefits minus the harm caused by their acts and enforcement costs, $x(p)$. We assume $x^{\prime}>0$ and $x^{\prime \prime}>0$ - that is, enforcement effort is subject to diminishing returns. Moreover, the maximum feasible sanction is $\bar{s}$, which can be interpreted as the maximum wealth of individuals where the sanction is a fine. We 
assume further that the sanction is costless to impose, as in the familiar Becker framework.

We depart from that familiar model by assuming that actors are imperfectly informed about $p$. Specifically, individuals observe $p$ with an error: they observe either $p+e(p)$ or $p-e(p)$, each with 50 percent probability. The government cannot observe each actor's estimate. We analyze first the baseline case in which $e(p)=0$ for all $p$ and then the case in which $e(p)>0$.

\section{B. Perfect Information}

When individuals accurately observe the probability of apprehension, all obviously observe the same $p$. The government's problem is to choose $p$ and $s$ so as to maximize

$$
\int_{p s}^{1}(b-h) d b-x(p)
$$

subject to the constraint that $s \leq \bar{s}$. The Becker result is immediate.

Proposition 1. When individuals accurately observe the probability of apprehension, the optimal sanction is maximal.

Proof. As one increases $s$ and reduces $x$ so as to keep ps constant, the first term in (1) is unaffected, and the magnitude of the second term falls, so the optimum is where the constraint is binding. Q.E.D.

\section{Imperfect Information}

When $e(p)>0$, individual probability estimates differ. The government's problem is to choose $p$ and $s$ so as to maximize

$$
\frac{1}{2} \int_{[p+e(p)] s}^{1}(b-h) d b+\frac{1}{2} \int_{[p-e(p)] s}^{1}(b-h) d b-x(p),
$$

subject to the constraint that $s \leq \bar{s}$.

Proposition 2. When individuals observe the probability of apprehension subject to an error, the optimal sanction may be less than the maximal one.

Proof. Begin with $s=\bar{s}$, and let $\bar{p}$ denote the optimal probability of apprehension given $\bar{s}$. Consider the effect on welfare of raising $p$ and reducing $s$, such that $p s$ remains fixed. Taking the derivative of (2) with respect to $p$, with $d s / d p=-s / p$, we obtain

$$
\begin{gathered}
\frac{1}{2}[h-(p+e) s]\left(s e^{\prime}-e s / p\right)+\frac{1}{2}[h-(p-e) s]\left(e s / p-s e^{\prime}\right)-x^{\prime} \\
=\left(e / p-e^{\prime}\right) e s^{2}-x^{\prime}
\end{gathered}
$$


where $e^{\prime}$ denotes $d e / d p$. If one assumes that, at $(\bar{p}, \bar{s}), d(e / p) / d p<0$ - that is, that the percentage error falls as $p$ rises-the first term is positive, reflecting an improvement in welfare from an improvement in behavior. It can readily be demonstrated that for enforcement technologies for which $x^{\prime}$ is not too large, the entire expression will be positive. ${ }^{5}$ Q.E.D.

The intuition behind proposition 2 is as follows. Beginning at the maximum feasible sanction and the probability that is optimal given this sanction, a reduction in the sanction accompanied by an increase in the probability that keeps the actual expected sanction constant will improve behavior whenever the relative size of the error-the ratio of the error to the actual probability-falls as the probability rises. (The example in Section I had this characteristic: the error was constant, so the relative error declined as the probability was increased.) Behavior improves because the perceived expected sanctions- $(p+e) s$ for some and $(p-e) s$ for others-move closer together. As a result, those who overestimate the probability are overdeterred less, and those who underestimate the probability are underdeterred less. ${ }^{6}$ As long as it is not too costly to raise the probability somewhat, the optimum will involve a sanction that is not maximal.

\section{Conclusion}

We have examined the problem of optimal enforcement when individuals are imperfectly informed about the probability of apprehension. When individuals observe this probability with some random error, it may be optimal to employ less than the maximum feasible sanction with a greater probability of apprehension. While raising the probability is costly, it may improve behavior. Behavior improves if the error is a lower fraction of the actual probability as this probability increases because less of a

\footnotetext{
${ }^{5}$ The demonstration is complicated only by the fact that the first term must be evaluated at $\bar{p}$, which itself depends on the technology $x(p)$. Examples can most easily be constructed using a less direct technique that avoids this interdependence. Set $\tilde{s}=\bar{s}$, and choose probability $\tilde{p}$ that maximizes the sum of the first two terms in (2)-that is, $\tilde{p}=h / \bar{s}-$ ee'. (Assume that the parameters are such that $\bar{p}<1$. Note that $\bar{p}>\bar{p}$.) Then consider $\hat{s}=$ $\bar{s} / \lambda$ and $\hat{p}=\lambda \bar{p}$, where $\lambda \epsilon(1,1 / \bar{p})$. Assume that $d(e / p) / d p<0$ for $p \epsilon[\tilde{p}, \hat{p}]$, so that behavior is better at the lower sanction and higher probability. Compute the degree to which welfare is greater as a result of this behavioral effect. Finally, assume that $x(\hat{p})$ is less than this benefit, which completes the example.

${ }^{6}$ Depending on $x(p)$, it may be that the optimal probability at $\bar{s}$ involves both groups being underdeterred. It is nonetheless true that behavior improves: the social benefit from reducing underdeterrence of those underdeterred substantially exceeds the loss from increasing underdeterrence of those underdeterred modestly, as the harm caused by both groups' acts is the same, but the benefit for the marginal individual in the former group is less than that for the latter.
} 
divergence in perceived expected sanctions will result. If behavior improves sufficiently, the higher enforcement cost will be warranted.

The importance of this phenomenon depends on the relationship between individuals' errors in estimating the probability of apprehension and the actual probability. The example we offered in the introduction suggests the plausibility of the assumption that errors are a greater fraction of the probability when probabilities are very low than when they are higher. To guide enforcement policy, empirical research on this point would be useful. For example, one might attempt to infer probability perceptions from behavior, which could be accomplished in an experimental setting, or to survey individuals concerning their perceptions. Work in cognitive psychology concerning probability perceptions might also illuminate the issue. Finally, one could examine analytically how individuals' probability estimates based on given priors and limited sets of observations differ when the probability generating the observations differs. ${ }^{7}$ Such research might reveal that relative errors are rather large for probabilities of apprehension that otherwise would be optimal with maximal sanctions, while much lower for the probabilities and sanctions actually observed.

7 Sah's model, supra note 3, assumes individuals' estimates are determined by their limited observations. For his purposes, only the crime rate and not the magnitude of individuals' errors is relevant, so he does not explore how such errors may be affected by the actual probability of apprehension. 